BMJ Nutrition,

Prevention \& Health

\title{
Mitigating the global health threat of violent conflict: a preventive framework
}

\author{
Daniel Shapiro (D) , ${ }^{1,2,3}$ Catherine Hua ${ }^{3,4}$
}

To cite: Shapiro D, Hua C. Mitigating the global health threat of violent conflict: a preventive framework. BMJ Nutrition, Prevention \& Health 2020;3:e000114. doi:10.1136/ bmjnph-2020-000114

${ }^{1}$ Psychiatry, Harvard Medical School/McLean Hospital, Boston, MA, USA

${ }^{2}$ Harvard Global Health Institute, Harvard University, Cambridge, MA, USA

${ }^{3}$ Harvard International Negotiation Program, Harvard University, Cambridge, MA, USA ${ }^{4}$ Global Health and Health Policy Undergraduate Program, Harvard University, Cambridge, MA, USA

Correspondence to Dr Daniel Shapiro, Psychiatry, Harvard Medical School, Boston, MA 02138, USA;

dlshapiro@law.harvard.edu

DS and $\mathrm{CH}$ contributed equally.

Received 5 June 2020

Revised 8 0ctober 2020

Accepted 13 October 2020

Published Online First

9 November 2020
Check for updates

(c) Author(s) (or their employer(s)) 2020. Re-use permitted under CC BY-NC. No commercial re-use. See rights and permissions. Published by BMJ.

\begin{abstract}
Objective To examine the problem of large-scale violent conflict and the unique preventive role that the global health community can play.
\end{abstract}

Methods We conducted a comprehensive literature review and extrapolated insights from practice-based research and consultation with leaders and grassroot organisations confronting emergent and ongoing large-scale conflict. Results The field of global health has thoroughly investigated the physical and mental health consequences of violent conflict, yet there is a dire need for preventive research and action.

Conclusions Global health scholars and practitioners are well-positioned to track early warning signs of violence, construct predictive models of its outbreak, lobby for policy reform to address the structural roots of conflict, and provide mediation and educational support to mitigate emerging conflict.

\section{INTRODUCTION}

Nearly 40 years ago, the World Health Assembly noted that 'the role of physicians and other health workers in the preservation and promotion of peace is the most significant factor for attainment of health for all'. ${ }^{1}$ This bold assertion is as true today as it was then. ${ }^{2}$ Large-scale violent conflict is among the most consequential determinants of global health, elevating transnational rates of mortality and morbidity and debilitating economic, social, and health systems. These high-stakes confrontations can occur between governments, between governments and non-governmental groups, or between non-state actors with access to weapons. ${ }^{3}$ Given the recent resurgence of armed conflict, ${ }^{4}$ both global health and public health communities have played an increasingly important role in stopping violent conflict, and while the field has studied the devastating impact of armed conflict on population health, ${ }^{5-7}$ there is a dire need for more research on conflict prevention.

It is our contention that global health communities can play a powerful role in violence mitigation. Prevention requires multistakeholder engagement at all levels of society, and the field of global health includes global and public health specialists, medical researchers and practitioners, 'multilateral
Summary box

What is already known about this subject?

- Large-scale conflict is a major global health problem that has enormous consequences on the physical, mental and social health of millions of people around the world.

What are the new findings?

- The field of global health has thoroughly investigated the consequences of armed conflict, yet there is a dire need for more research on conflict prevention.

What are the recommendations for policy and practice?

- The global health community should incorporate empirically supported conflict prevention and mediation strategies to existing violence prevention models. Specific approaches can include tracking early warnings of violence, creating predictive models of its outbreak, and working with local public health and medical experts to mitigate emerging conflict.

and international organisations, donor and partner governments, the private sector, research organisations, civil society, academia and individuals'. ${ }^{8-10}$ Channelling this vast network's energies to promote conflict resolution can have a substantial impact on violence prevention and global health.

In this article, we explain why large-scale violent conflict is a major global health concern, elaborate on the field's tendency to study the aftermath of conflict, and offer novel ways for global health researchers and practitioners to contribute to conflict prevention. These perspectives derive from the Harvard International Negotiation Program's research and fieldwork as well as from the corresponding author's experiences consulting in high-stakes conflicts in the Middle East, Europe, North America and East Asia.

\section{VIOLENT CONFLICT: A MAJOR GLOBAL HEALTH ISSUE}

Large-scale violent conflict is a global health concern of great magnitude. In line with wellestablished criteria of global health, ${ }^{11}$ such 
conflict transcends national boundaries; may be influenced by international circumstances or experiences; is best addressed through cooperative, multidisciplinary action; and has a substantial direct and indirect impact on population health.

The direct impact of armed conflict on physical, mental and social well-being is profound. Conflict-ridden regions have some of the world's highest rates of injury ${ }^{12}$ and are recipients of $86 \%$ of international assistance for malnutrition. ${ }^{13}$ In the 25 largest instances of collective violence in the 20th century, an estimated 191 million people$60 \%$ civilians-lost their lives. ${ }^{14}{ }^{15}$ With regard to mental health, at least $22 \%$ of individuals in conflict-affected regions suffer from mental illness such as depression, post-traumatic stress disorder and bipolar disorder. ${ }^{16}$ Armed conflict also alters family structure due to imprisonment, forced relocation, military recruitment and loss of parental figures. ${ }^{1718}$

The indirect impact of armed conflict on global health is equally alarming. The number of people forcibly displaced by violent conflict and human rights violations has increased $63.5 \%$ : from 43.4 million people in 2009 to 70.8 million in 2018. ${ }^{19}$ Meanwhile, escalating conflicts in the Middle East are associated with the spread of infectious diseases such as cholera, poliomyelitis, measles and diphtheria, affecting over 1 million individuals since $2014 .^{20}$ The signing of peace agreements often does little to preclude large-scale indirect burdens on global health. For example, in the Democratic Republic of Congo 5 years after rebel groups and opposition political parties signed a historic peace treaty, an estimated 2.1 million deaths resulted from indirect causes such as mass population flow, spread of infectious disease and pregnancy complications. ${ }^{21}$

What should be done? For decades, the global health community has investigated the direct and indirect effects of armed conflict on health and has provided on-theground medical support through international and local health organisations ${ }^{5-7}$-but despite the importance of such work, these efforts address the aftermath of conflict, not the roots. This is analogous to a doctor treating a woman week after week for bruised ribs and broken bones but failing to help prevent the cause-domestic abuse. To break free of this cycle, the structural and sociopolitical roots of conflict also must be addressed, and the global health community is wellpositioned to bring its knowledge and methodologies to this effort.

\section{THE PREVENTION PRINCIPLE: ADDRESSING THE PRECURSORS OF CONFLICT}

The prevention principle, proposed by Shapiro and Kinon, suggests that the global health community can best prevent violent conflict by addressing its precursors 'at the earliest possible time at the lowest legitimate level'. ${ }^{22}$ The earlier one acts to prevent violence, the less damage there will be to population health and economic security; and the more localised and credible the stakeholders involved in the intervention, the more likely they will account for the nuanced political, historical and cultural context.

A comprehensive approach to prevention must address conflict's structural and situational roots. At the structural level, the global health community can promote initiatives to address inequalities in access to social services, political power, status and wealth. ${ }^{23}$ For example, global health practitioners can create a multistakeholder coalition on the prevention of violent conflict that lobbies for structural reform and laws that respect the dignity of all members of society. ${ }^{24}$ This coalition could launch an international campaign to mobilise the insights and authority of the global health community to promote peaceful societies, building on the work of organisations such as the International Physicians for the Prevention of Nuclear War and its Campaign to Prevent Armed Violence. ${ }^{25} 26$

The global health community also has an important role to play in mitigating the situational roots of conflictthe local, on-the-ground triggers that exacerbate tension. First, global health scholars can collaborate with public health specialists and local conflict resolution experts to research early warning systems, building on epidemiological modelling of disease tracking to improve statistical indicators and qualitative measures of emerging conflict within and across borders. ${ }^{27} 28$ Because individuals suffering from conflict-inflicted injury often seek out medical help, health systems often have unique access to data on early warning signs of incipient conflict.

Second, global health leaders can 'immunise' groups from violent conflict and its downstream effects through formal and informal educational initiatives. Global health workers can gain skill in culturally tailored consensusbuilding methods, model those behaviours and promote their widespread application. Local health professionals can collaborate with schools to teach students practical, widely accepted concepts of constructive conflict resolution such as the importance of perspective taking and looking beneath a disputant's stated position to understand underlying interests. Global health leaders can join with non-partisan conflict resolution organisations to train top decision makers in interest-based negotiation, an empirically supported method to help disputants shift from staunch political postures to mutually satisfying agreements. ${ }^{29} 30$

Third, global health leaders can facilitate formal and informal dialogue between opposing stakeholders. Indeed, some medical doctors have already embraced this role. ${ }^{31}$ In many contexts, health leaders are uniquely situated to serve as third party facilitators, as they are often viewed as less biased guardians of human welfare than government representatives or international intervenors. In a facilitative role, they can organise private meetings with key stakeholders, lead joint problem solving workshops, issue public statements urging non-violent approaches to conflict resolution and warn opposing leaders about the massive health impact of war on women, men and children. ${ }^{32}$ 
Despite the great need for conflict prevention, global health scholars and medical professionals are already overloaded with research, field responsibilities and the litany of health issues to be tackled. Our intent is not to burden these specialists with new obligations but to urge the field to expand its focus over time-and there are many ways to do so. First, university programmes in global health can add new courses on negotiation and mediation as well as on methods for investigating the emergence, tracking and mitigation of violent conflict, opening formalised interest in this domain to an emerging generation of global health leaders. Second, global and public health graduate programmes and medical schools can invest in research on correlations between population health and conflict prevention. Third, global health programmes and medical institutions can train health professionals in methods to address structural and situational aspects of emergent conflict. Fourth, local global health professionals can establish conflict mitigation teams that include health specialists, leaders of medical institutions, regional diplomats and agents of intergovernmental organisations such as the United Nations-and convene working sessions on the prevention of violent conflict. Finally, philanthropic organisations can promote the expansion of global health by establishing grants and sponsoring conferences on conflict prevention. Combined, these efforts can form a tidal wave of new research and educational possibilities that promote global health, reduce large-scale suffering and save lives.

\section{CONCLUSION}

According to the World Health Organization, 'investing in health is investing in peace, ${ }^{, 33}$ but promoting peace is also an investment in health. Armed conflict is a global health problem of the highest order with massive direct and indirect consequences on mortality and morbidity. While the medical field has traditionally concentrated on the aftermath of violent conflict, the field's expansion to the arena of conflict prevention heralds an important advancement toward the vision of health for all.

Acknowledgements The authors wish to thank David Cutler and Christy Colburn of the Global Health and Health Policy Undergraduate Program at Harvard University as well as the anonymous reviewers who provided insightful feedback.

Contributors All authors contributed equally to this work.

Funding The authors have not declared a specific grant for this research from any funding agency in the public, commercial or not-for-profit sectors.

Competing interests None declared.

Patient consent for publication Not required.

Provenance and peer review Not commissioned; externally peer reviewed.

Open access This is an open access article distributed in accordance with the Creative Commons Attribution Non Commercial (CC BY-NC 4.0) license, which permits others to distribute, remix, adapt, build upon this work non-commercially, and license their derivative works on different terms, provided the original work is properly cited, appropriate credit is given, any changes made indicated, and the use is non-commercial. See: http://creativecommons.org/licenses/by-nc/4.0/.
ORCID iD

Daniel Shapiro http://orcid.org/0000-0001-5438-4589

\section{REFERENCES}

1 Petersen. World Health Organization Seventh Report of Committee B [Internet]. Available: https://apps.who.int/iris/bitstream/handle/10665/ 155678/WHA34_45_eng.pdf? sequence=1\&isAllowed=y

2 McCoy D. Re-engaging the health community around peace. Lancet 2015;386:1714-6.

3 How is the term "Armed Conflict" defined in international humanitarian law? - ICRC [Internet]. Available: /eng/resources/ documents/article/other/armed-conflict-article-170308.htm

4 World Bank United Nations. Pursuing Pathways for Peace: Recommendations for Building Inclusive Approaches for Prevention. In: Pathways for Peace: Inclusive Approaches to Preventing Violent Conflict [Internet]. The World Bank, 2018: 275-94. https://elibrary. worldbank.org/doi/10.1596/978-1-4648-1162-3_ch8

5 Beaglehole R, Bonita R. What is global health?. Global Health Action 2010;3.

6 Spiegel PB, Checchi F, Colombo S, et al. Health-care needs of people affected by conflict: future trends and changing frameworks. Lancet 2010;375:341-5.

7 Levy BS, Sidel VW. Documenting the effects of armed conflict on population health. Annu Rev Public Health 2016;37:205-18.

8 Fried LP, Bentley ME, Buekens P, et al. Global health is public health. Lancet 2010;375:535-7.

9 Koplan JP, Bond TC, Merson MH, et al. Towards a common definition of global health. Lancet 2009;373:1993-5.

10 KFF. The U.S. Government Engagement in Global Health: A Primer Report [Internet], 2019. Available: https://www.kff.org/report-section/ the-u-s-government-engagement-in-global-health-a-primer-report/

11 "America's Vital Interest in Global Health: Protecting Our People, Enhancing Our Economy, and Advancing Our International Interests" at NAP.edu [Internet]. Available: https://www.nap.edu/read/5717/ chapter/4

12 Haagsma JA, Graetz N, Bolliger I, et al. The global burden of injury: incidence, mortality, disability-adjusted life years and time trends from the global burden of disease study 2013. Inj Prev 2016;22:3-18.

132018 Global Nutrition Report [Internet]. Available: https:// openaccess.city.ac.uk/id/eprint/22797/1/2018_Global_Nutrition_ Report.pdf

14 Krug EG. World report on violence and health. Geneva: Weltgesundheitsorganisation, 2002: 346.

15 Rummel RJ. Death by government: genocide and mass murder since 1900. Routledge, 2018: 521.

16 Charlson F, van Ommeren M, Flaxman A, et al. New WHO prevalence estimates of mental disorders in conflict settings: a systematic review and meta-analysis. Lancet 2019;394:240-8.

17 MacDermid Wadsworth SM, Wadsworth SMM. Family risk and resilience in the context of war and terrorism. $J$ Marriage Fam 2010;72:537-56.

18 Loveless AS, Holman T. The family in the new millennium: strengthening the family. Greenwood Publishing Group, 2007: 458.

19 UNHCR Global Trends. Global Trends - Forced Displacement in 2018 - UNHCR [Internet], 2018. Available: https://www.unhcr.org/ globaltrends2018/

20 Raad II, Chaftari A-M, Dib RW, et al. Emerging outbreaks associated with conflict and failing healthcare systems in the middle East. Infect Control Hosp Epidemiol 2018;39:1230-6.

21 Mortality in the Democratic Republic of Congo an ongoing crisis [Internet]. Available: https://www.rescue.org/sites/default/files/ document/661/2006-7congomortalitysurvey.pdf

22 Shapiro D, Kinon A. The prevention principle: a pragmatic framework to prevent destructive conflict. J Int Dispute Settl 2010;1:301-12.

23 Leander SS. Structural violence and conflict: Vertical and horizontal inequality in post-genocide Rwanda. In: Horizontal inequalities and Post-Conflict development. London: Palgrave Macmillan, 2012: 230-48.

24 Hicks D. Dignity: the essential role it plays in resolving conflict. Yale University Press, 2011: 241 p.

25 Institute for Economics \& Peace. Positive Peace Report 2019: Analysing the Factors that Sustain Peace [Internet], 2019. Available: https://www.economicsandpeace.org/wp-content/uploads/2020/08/ PPR-2019-web.pdf

26 Aiming for Prevention IPPNW's Campaign to Prevent Armed Violence [Internet]. Available: https://www.ippnw.org/afp.html

27 McDonnell SM, Bolton P, Sunderland N, et al. The role of the applied epidemiologist in armed conflict. Emerg Themes Epidemiol 2004;1:4. 
28 The Public Health Approach to Violence Prevention - CDC [Internet], 2020. Available: https://www.cdc.gov/violenceprevention/ publichealthissue/publichealthapproach.html

29 Fisher R, Ury WL, Patton B. Getting to Yes: negotiating agreement without giving. Penguin, 2011: 150.

30 Fisher R, Shapiro D. Beyond reason: using emotions as you Negotiate. Penguin, 2005: 362 p.

31 Volkan VD. Large-group psychodynamics and massive violence. Ciênc Saúde Coletiva 2006;11:303-14.
32 International Peace Institute. Doctors in War Zones: International Policy and Healthcare During Armed Conflict [Internet], 2018.

Available: https://www.ipinst.org/2018/06/doctors-in-war-zones

33 The World Health Organization Department of Emergency and Humanitarian Action Conflict and Health Working paper as presented at the international seminar Preventing Violent Conflict - The Search for Political Will, Strategies and Effective Tools [Internet]. Available: https://www.who.int/hac/techguidance/hbp/ Conflict.pdf 